\title{
Role of unbalanced slab resistive force in the 2004 off Sumatra mega-earthquake $\left(M_{\mathrm{w}}>9.0\right)$ event
}

\author{
Prosanta Kumar Khan
}

Received: 14 August 2009/ Accepted: 3 July 2010 / Published online: 12 August 2010

(C) The Author(s) 2010. This article is published with open access at Springerlink.com

\begin{abstract}
Present study addresses the role of major platedriving forces, particularly the slab pull and slab resistive forces, for the generation of 26 December $2004 M_{\mathrm{w}}>9.0$ off Sumatra megathrust earthquake. Major controls on the plate-driving forces are normally visualized through age, speed, and average dip of the slab during subduction. Wide variation in age, plate obliquity, stress obliquity, subduction rate, dip angle, and flexing depth of the subducting oceanic lithosphere between Andaman and Sumatra thus allowed us for quantitative evaluation of the slab pull $\left(F_{\mathrm{SP}}\right)$ and slab resistive $\left(F_{\mathrm{SR}}\right)$ forces in three well-defined sectors (I, II and III). Computed values of these forces in the three sectors: (1) $F_{\mathrm{SP}}=1.29 \times 10^{13} \mathrm{~N} / \mathrm{m}, F_{\mathrm{SR}}=1.41 \times 10^{13} \mathrm{~N} / \mathrm{m}$; sector I, (2) $F_{\mathrm{SP}}=2.10 \times 10^{13} \mathrm{~N} / \mathrm{m}, F_{\mathrm{SR}}=1.13 \times 10^{13} \mathrm{~N} / \mathrm{m}$; sector II, and (3) $F_{\mathrm{SP}}=2.08 \times 10^{13} \mathrm{~N} / \mathrm{m}, F_{\mathrm{SR}}=2.72 \times$ $10^{13} \mathrm{~N} / \mathrm{m}$; sector III clearly suggest a spatial variation of stress regime in the subducting oceanic lithosphere. Excess $F_{\text {SR }}$ in sectors I and III are interpreted as the causative forces behind the triggering of major seismic energy bursts near Sumatra and Andaman on 26 December 2004. A gap of minimum seismic energy burst near Great Nicobar possibly was controlled by the excess of $F_{\mathrm{SP}}$ in sector II. This study further advocates that the cyclic stress, resulted from unbalanced component of slab resistive force, had a definite control on the occurrence of 2004 off Sumatra megathrust earthquake around the flexing zone of the subducting lithosphere.
\end{abstract}

Keywords Megathrust earthquake - Flexing zone . Slab pull force $\cdot$ Slab resistive force $\cdot$ Stress loading

P. K. Khan $(\bowtie)$

Department of Applied Geophysics, Indian School of Mines, Dhanbad, India

e-mail: pkkhan_india@yahoo.com

\section{Introduction}

Since the inception of continental drift and sea-floor spreading hypothesis, Earth scientists were principally involved in evaluating the kinematics of plate motions visà-vis the theory of plate tectonics. After the introduction of plate guiding stresses (Elsasser 1969) and formulation of plate tectonics (McKenzie 1969), several scientists (Forsyth and Uyeda 1975; Harper 1975; Solomon et al. 1975) were encouraged in understanding the plate kinematics, and subsequently, driving mechanisms of lithospheric plates were evolved. Incidentally, Isacks and Molnar (1969) interpreted quite convincingly the occurrence of mantle earthquakes in the backdrop of plate tectonics, and several hypothesis were put forward over more than three decades to appreciate the geological processes behind the occurrence of great to mega-earthquakes at the shallower part $(<60 \mathrm{~km})$ of the subducting lithosphere at the plate margins around the world. In this connection, Forsyth and Uyeda (1975) first suggested that the slab pull $\left(F_{\mathrm{SP}}\right)$ and slab resistive $\left(F_{\mathrm{SR}}\right)$ are the major plate-driving forces apparently control the dynamic equilibrium of the plates, and successfully explained the spatial variation of stress regime in the subducting oceanic lithosphere. They also invoked that $F_{\mathrm{SP}}$ and $F_{\mathrm{SR}}$ along the longitudinal profiles of the descending plate dictate the major intraplate failure for mega-earthquake generation $\left(M_{\mathrm{W}} \geq 8.5\right)$ at the shallower level of the lithosphere (Forsyth and Uyeda 1975; Khan and Chakraborty 2009). Further, the flexing zone of the lithosphere beneath the trench during subduction suffers instability by the net effect of slab pull and slab resistive forces (Marotta and Mongelli 1998), and 60\% of the energy associated with the subducting slab is normally dissipated through the bending segment of the slab (Conrad and Hager 1999). Invariably recorded shallowest 
dip, lowest flexing depth (Widiyantoro and Van der Hilst 1997; Khan and Chakraborty 2005), youngest plate age ( $\sim 47 \mathrm{Ma}$ in northwest Sumatra, increases to $\sim 152 \mathrm{Ma}$ towards east near Java and $\sim 67$ Ma towards north near North-Andaman, Muller et al. 1997) of the subducting lithosphere, minimum slip vector residual (Liu et al. 1995, Khan 2007), intermittent occurrence of megathrust earthquake $(1797 \mathrm{M} \sim 8.4,1833 \mathrm{M} \sim 9.0,1861 \mathrm{M} \sim 8.5$, Lay et al. 2005; $M_{\mathrm{w}}>9.0,2005 M_{\mathrm{w}} 8.6$, Ammon et al. 2005, 9.3; Stein and Okal 2005), and recently proposed strain-hardened model for mega-earthquakes (Khan and Chakraborty 2009) allowed us for understanding the role of major plate-driving forces (Forsyth and Uyeda 1975) for the occurrence of 2004 off Sumatra event.

Recurrence of major seismic energy bursts (Ishii et al. 2005), activation of three isolated fault segments in the southern, central and northern part (Dasgupta et al. 2005), and identified high stress condition (Mishra et al. 2007; Walter and Amelung 2007) along the Andaman-Sumatra margin during the 2004 event do not support the sectorspecific stationarity of coupling arises from seamounts/ asperity subduction (Dmowska et al. 1996). Instead, the 2004 event can be identified in the backdrop of minimum stress obliquity (Khan 2007), lowest flexing depth, shallowest dip angle, and two-stage opening of Andaman Sea from the off Sumatra area (Khan and Chakraborty 2005). Further, a poor correlation between subduction dynamics and seismic coupling $(\chi)$ as reported by Pacheco et al. (1993) and a wide variation of $\chi$ i.e. high to very high ( $\chi=0.6$ to 1.00, Scholz and Campos 1995; Prawirodirdjo et al. 1997) intermediate (Christensen and Ruff 1988) and very low $(\chi=0.02-0.05$, Peterson and Seno 1984; Pacheco et al. 1993) allow estimation of major platedriving forces in the Sumatra area. A causal relationship between these major plate-driving forces and the geodynamic processes established under the present study for the Andaman-Sumatra margin clearly indicates that 2004 off Sumatra mega-earthquake was not unexpected in this area.

\section{Late tertiary tectonics around Andaman-Sumatra region}

Sumatra margin, a transitional domain between the zones of frontal subduction of the Indo-Australian plate around Java towards east and oblique subduction of the Indian plate around Andaman towards north, recorded interference of multiple tectonic elements (Fig. 1), complex pattern of late Tertiary lithospheric deformation, and strong anomalous strain partitioning (Diament et al. 1992; Hall 1997; McCaffrey et al. 2000; Barber and Crow 2003; Metcalfe 2006). A $\sim 40 \mathrm{~mm} /$ year trench-normal convergence rate was recorded near the epicentre of 2004 off
Sumatra earthquake (Paul et al. 2001). Subsurface anomalous behaviour of the descending oceanic lithosphere with concomitant trench-parallel shifting of the Burma sliver plate and subsequent two-phase opening of the marginal basins in form of Mergui-Sumatra and Andaman Sea (Le Dain et al. 1984; Maung 1987; Raju et al. 2004; Khan and Chakraborty 2005) are the major late Tertiary geological events, and those were initiated from the northwest Sumatra and propagated towards north along the AndamanSumatra subduction margin. Enhanced convergence and increased plate obliquity (i.e. angle between converging plate velocity vector and normal to the trench) between the Indian and Eurasian plates (Fitch 1972; Patriat and Achache 1984), northward journey of the tangentially converging hanging Indian lithosphere through the surrounding asthenosphere (Le Dain et al. 1984; Curray 2005), clockwise rotation of the Sumatra-arc (Ninkovich 1976), and counter-clockwise rotation of north Sumatra and south Malaya (Hall 1997) resulted the offsetting of the Burma sliver plate (Le Dain et al. 1984; Maung 1987) and triggered the opening of the marginal basins. The opening of the Mergui and Andaman basins was accommodated along major strike-slip Sagaing fault in the north and Sumatra fault system in the south (Curray 2005). The change in direction of the northwestward opening of the Andaman Sea towards north and later northeastward was presumably associated with the fore-arc deformation (Khan and Chakraborty 2005) all along this margin. A temporary halt in rifting at the pull-apart opening stage and northeastward veering of the Andaman sea ridge (ASR) were apparently controlled by upliftment of oceanic crust in post-middle Miocene time in form of Alcock and Sewell seamounts, lying symmetrically north and south of this spreading ridge. The major geological incidences were concealed in the records of trench-normal segmentation all through the descending Indian lithosphere along the Andaman-Sumatra margin (Dasgupta et al. 2003).

\section{Benioff zone reconstruction}

Earthquake data $\left(m_{\mathrm{b}} \geq 4.0\right)$ those lying within the downgoing oceanic Indian lithosphere and recorded at 15 or more stations between latitudes $2.0^{\circ}$ and $10.4^{\circ} \mathrm{N}$ (Fig. 2) are considered for reconstruction of the Benioff zone configuration. The dataset were taken from ISC (International Seismological Centre) Bulletin covering the period between 1964 and 1999. The north-south extension of the study area is constrained by the 2004 off Sumatra megaevent rupture characteristics (Ammon et al. 2005; Ishii et al. 2005; Lay et al. 2005). For understanding the mutual interaction between the major plate-driving forces, the area was divided into three sectors on the basis of major seismic 
Fig. 1 Top map showing the tectonic framework of NicobarSumatra margin (after Curray 2005; Curray and Munasinghe 1991). Bottom map showing the location of the study area. Note the age variation of descending oceanic plate along the Sunda margin (after Muller et al. 1997) in the location map. Left bottom solid arrow indicates Indian plate velocity vector, and right top open arrow is for major block motion with respect to Siberia since the Miocene. Solid star with beach ball represent the epicentre and focal mechanism of the mainshock. Contour lines (after Ishii et al. 2005) represent in percentage of the maximum seismic energy release associated with the Sumatra earthquake of 26 December 2004. Note the two major seismic energy bursts near Sumatra and Nicobar Islands with a minima near Great Nicobar. The right top inset in the top map shows the sector-specific variation of plate converging obliquity (a) and trench-normal subduction (b) in different time steps (after Khan and Chakraborty 2005)

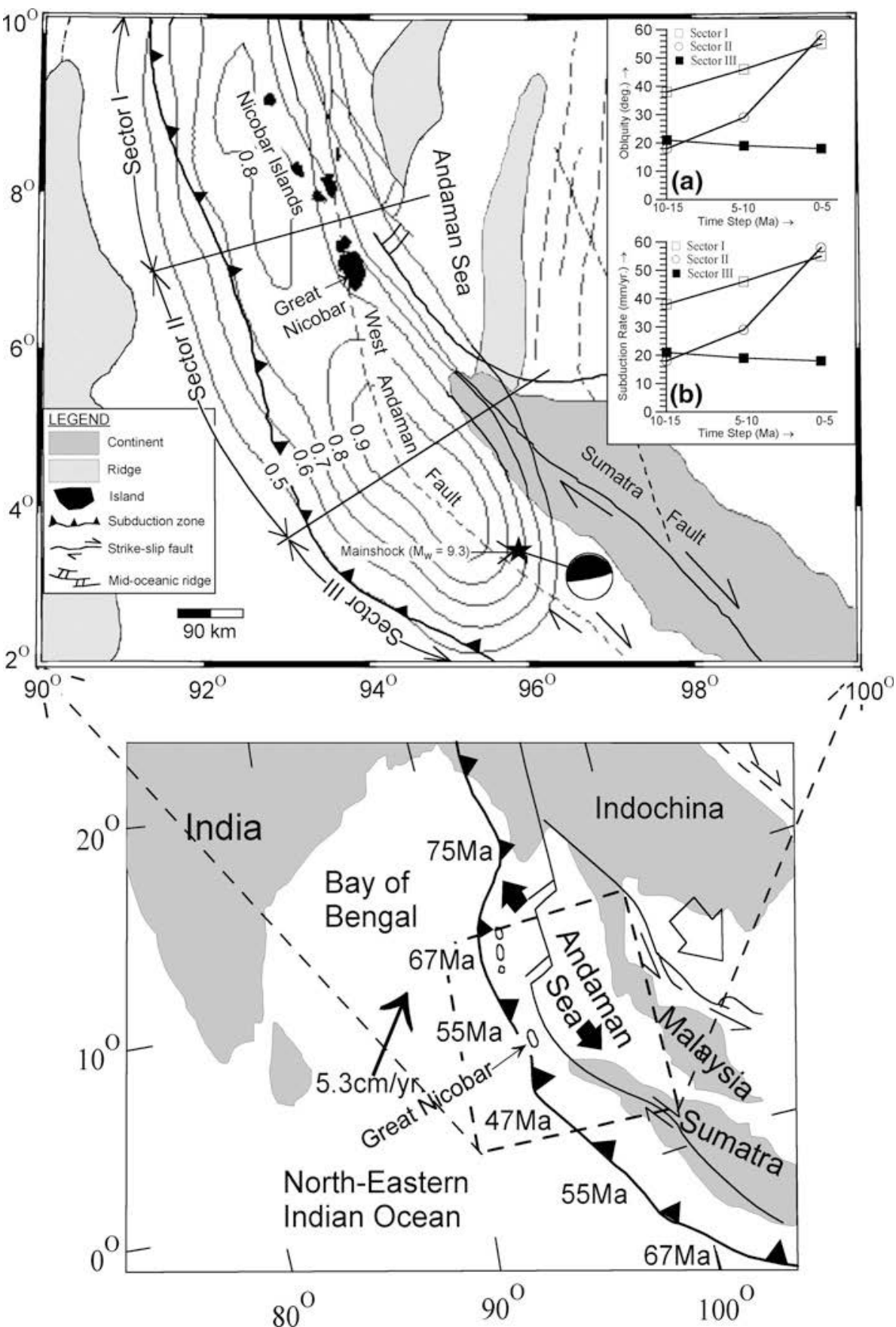

energy bursts during 2004 event (Ishii et al. 2005), preseismic stress fields (Khan 2007), and major geological incidences along this plate margin. The Benioff zone geometries in the three sectors were reconstructed based on the distribution of the intraplate historical earthquake data (Khan and Chakraborty 2005) and the age-dependent platethickness (expressed as $2\left(\mathrm{kt}_{\mathrm{c}}\right) 1 / 2$, where $t_{\mathrm{c}}$ is the age of the descending plate at the trench and $k=10^{-6} \mathrm{~m}^{2} \mathrm{~s}^{-1}$ is the thermal diffusivity) (Conrad and Lithgow-Bertelloni 2002).

A literature survey for the Benioff zone reconstruction process using intraplate earthquake data reveals that the procedures for delineating both upper and lower surfaces have some inherent inconsistency. The actual trend of the upper surface of the Benioff zone trajectory can be delineated with the best fit of hypocentral distribution (Ponko and Peacock 1995; Christova 2004). Instead, the delineation of lower surface can not reliably be determined using only hypocentral distribution as the seismogenic layer is limited and always less in thickness than the actual thickness of the descending oceanic lithosphere (Watts and Burov 2003). The delineation of the lower surface was thus demarcated by using both earthquake database (Fig. 2) and 
Fig. 2 Map showing the historical seismicity (open triangle) distribution. $\mathrm{AB}, \mathrm{CD}$, and $\mathrm{EF}$ are three profiles in the three sectors I, II, and III along which the high-resolution configurations of the Benioff zones (see Fig. 4) were reconstructed. Right top inset in the map showing the sectorspecific magnitude of the downdip component of slab pull force $\left(F_{\mathrm{SP}}\right)$, slab-normal component of slab pull force $\left(F_{\mathrm{SN}}\right)$, and slab resistive force $\left(F_{\mathrm{SR}}\right)$. Note the excess values of $F_{\mathrm{SR}}$ over $F_{\mathrm{SP}}$ in sectors I (near Nicobar Islands) and III (near Sumatra), and the less values in sector II (near Great Nicobar)

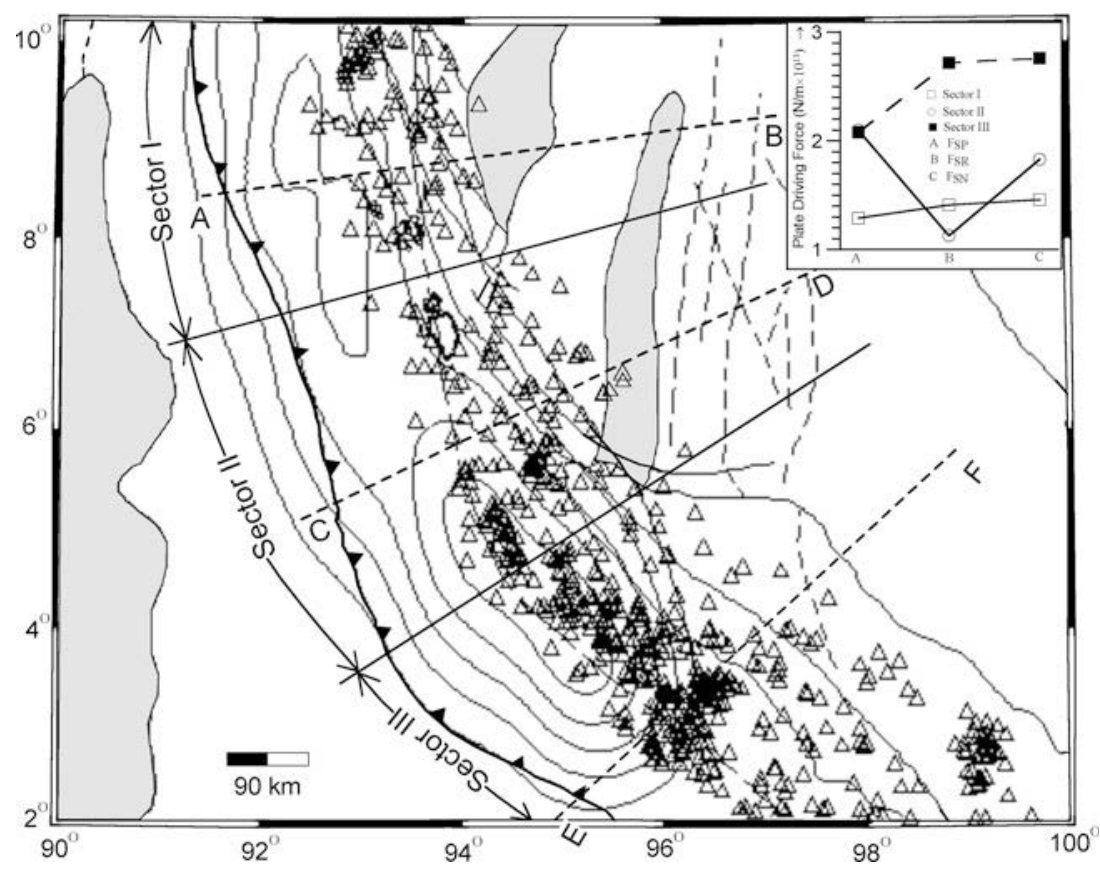

well-defined plate age (Muller et al. 1997). The sectorspecific configurations of the convection cells were reconstructed following the works of Kincaid and Sacks (1997). The cell concentration in the mantle wedge is likely constrained by the temperature, depth of serpentinisation of the fore-arc mantle (Kincaid and Sacks 1997; Hyndman and Peacock 2003), and sharp variation of dip (Khan and Chakraborty 2005).

\section{Implications of plate-driving forces}

The journey of the oceanic lithosphere from constructive margins (e.g. mid-oceanic ridges) to consuming margins (e.g. subduction zones at the plate margin) is presumably controlled by a variety of plate-driving forces viz. ridge push $\left(F_{\mathrm{RP}}\right)$, slab pull $\left(F_{\mathrm{SP}}\right)$, slab resistive $\left(F_{\mathrm{SR}}\right)$, basal drag/ mantle drag $\left(F_{\mathrm{DR}}\right)$, and trench suction $\left(F_{\mathrm{SUC}}\right)$ (McKenzie 1969; Forsyth and Uyeda 1975; Harper 1975; Solomon et al. 1975). The ridge-normal push force is generally originated around the ridge crest due to elevated topography through cooling and thickening of the oceanic lithosphere (Forsyth and Uyeda 1975) and is estimated to be small enough (of the order of $10^{12} \mathrm{~N} / \mathrm{m}$, Harper 1975; Parsons and Richter 1980) compared to slab pull force, sometimes less than $\sim 10 \%$ (Lithgow-Bertelloni and Richards 1998). Slab pull force arises from negative buoyancy of the oceanic lithosphere during penetration into the mantle and is reported to be a major plate-driving force that causes the motion of the plate (McKenzie 1969; Forsyth and Uyeda 1975; Harper 1975; Solomon et al. 1975), and estimated as an order of magnitude larger than
$F_{\mathrm{RP}}$ (Turcotte and Schubert 1982). Besides the negative buoyancy force, the slab, during penetration into the mantle, experiences resistance due to viscous drag. The viscous drag/slab resistive force is estimated to be very large, comparable to the order of slab pull force (Forsyth and Uyeda 1975).

The surface plate at the trench and the deeper slab in the mantle experience the mutual interaction of the slab pull and slab resistive forces, and thereby, the slab penetrates into the mantle under the control of these forces (Richardson 1992). The penetration velocity either less (if $F_{\mathrm{SR}}<F_{\mathrm{SP}}$ ) or greater (if $F_{\mathrm{SR}}>F_{\mathrm{SP}}$ ) than terminal velocity (Isacks and Molnar 1971; Forsyth and Uyeda 1975). On the other hand, the basal drag/mantle drag force is small and poorly constrained (Richardson et al. 1979), and the trench suction force (a fraction of the slab pull force, Scholz and Campos 1995) generally arises due to dynamic motion of the convection cells and causes both the subducting and overriding plates to move towards trench axis. Moreover, the slab pull and slab resistive forces are an order of magnitude more than the other forces (c.f., Table 6 of Forsyth and Uyeda 1975). In the present study, these two major forces were quantitatively assessed along the Andaman-Sumatra margin, and their controls on the trench-parallel rupture propagation vis-à-vis occurrence of 2004 mega-event were investigated.

\section{Estimation of slab pull and slab resistive forces}

Owing to the significance of plate-driving forces around the Sumatra margin, we estimated the forces acting on the 
slab as (1) velocity-independent slab pull force, and (2) velocity-dependent slab resistive force (Forsyth and Uyeda 1975). The slab pull force along the length of the descending slab, resulted from negative buoyancy, can be expressed as

$F_{\mathrm{SP}}=\Delta \rho \cdot g \cdot V \cdot \operatorname{Sin} \delta_{\mathrm{av}}$

where $F_{\mathrm{SP}}$ is taken towards down-dip direction of the slab, and the slab normal downward component of $F_{\mathrm{SP}}$ (i.e. $\left.F_{\mathrm{SN}}=\Delta \rho \cdot g \cdot V \cdot \cos \delta_{\mathrm{av}}\right)$ is balanced by hydrodynamic lifting torque generated by a reactive flow in the mantle wedge above the slab (Turcotte and Schubert 1982; Scholz and Campos 1995) and control its dip during penetration into the mantle (Hager and O'Connell 1978). $\Delta \rho$ is the density contrast between descending lithospheric slab and surrounding asthenosphere, $\mathrm{g}$ acceleration due to gravity, and $\mathrm{V}$ volume of the slab. The densities of the lithosphere and asthenosphere are not well constrained. However, the density contrast $\Delta \rho$ can be well determined based on observed subsidence of the sea floor with plate cooling (cf. Fig. 1 of Cloos 1993). This allowed us to determine the variation of density contrast with lithospheric thickness, and hence $\Delta \rho$ was estimated for the Sumatra margin. Volume of the slab $(V)$ in the three sectors (I, II and III) was estimated using basic software.

The slab resistive force, which opposes the motion of the descending slab into the mantle, is expressed as

$F_{\mathrm{SR}}=6 \pi \eta_{\mathrm{av}} r_{\mathrm{e}} v_{\mathrm{s}}$

where $\eta_{\mathrm{av}}$ is the average viscosity over the depth range of the slab, $r_{\mathrm{e}}$ is the effective radius of the slab, and $v_{\mathrm{s}}$ is the trench-normal subduction rate (Table 1). Viscosity is another very fundamental parameter, like density, for the earth's inner material, and again very poorly constrained.

Table 1 Sector-specific computed parameters, related to subduction of the oceanic Indian lithosphere, were used to estimate the slab pull force $\left(F_{\mathrm{SP}}\right)$, slab-normal force $\left(F_{\mathrm{SN}}\right)$, and slab resistive force $\left(F_{\mathrm{SR}}\right)$

\begin{tabular}{llll}
\hline & Sector I & Sector II & Sector III \\
\hline $\begin{array}{l}\text { Volume of the hanging } \\
\text { slab }(\mathrm{V})\left(\mathrm{km}^{3} \times 10^{7}\right)\end{array}$ & 1.07 & 1.32 & 0.8 \\
$r_{\mathrm{e}}(\mathrm{km})$ & 136.9 & 146.8 & 124.8 \\
$v_{\mathrm{S}}(\mathrm{mm} / \mathrm{s})$ & 36.55 & 34.01 & 39.16 \\
$\delta_{\text {av }}(\mathrm{deg})$. & 41.3 & 48.9 & 37.0 \\
Thickness of the slab $(\mathrm{km})$ & 90.6 & 83.3 & 77 \\
Average depth of penetration & 155 & 272 & 215 \\
$\quad$ of the slab $(\mathrm{km})$ & & & \\
$\eta_{\mathrm{av}}\left(\mathrm{Pa}-\mathrm{S} \times 10^{21}\right)$ & 1.87 & 1.43 & 1.87 \\
$\Delta \rho\left(\mathrm{kg} / \mathrm{m}^{3}\right)$ & 73.5 & 80.7 & 87.1 \\
$F_{\mathrm{SP}}\left(\mathrm{N} / \mathrm{m} \times 10^{13}\right)$ & 1.29 & 2.10 & 2.08 \\
$F_{\mathrm{SN}}\left(\mathrm{N} / \mathrm{m} \times 10^{13}\right)$ & 1.46 & 1.83 & 2.76 \\
$F_{\mathrm{SR}}\left(\mathrm{N} / \mathrm{m} \times 10^{13}\right)$ & 1.41 & 1.13 & 2.72 \\
\hline
\end{tabular}

There are basically two independent approaches available to understanding the viscosity profile within the Earth: (1) parameters related to isostatic adjustment over the time frame of glacial cycles (Nakada and Lambeck 1989; Mitrovica 1996; Mitrovica and Forte 2004), and (2) data related to physical deformation properties linked to the convection processes (King and Masters 1992; Corrieu et al. 1994; Panasyuk and Hager 2000). Both the methods have some advantages and drawbacks, and hence the depth variation of mantle viscosity was reconstructed several times (Mitrovica 1996; Mitrovica and Forte 2004). It is therefore realistic to appreciate the mantle viscosity profile computed by Mitrovica and Forte (2004) on the basis of non-linear, iterative, Occam-style joint inversions of extensive data set (e.g. shorter wavelength gravity anomalies, the dynamic surface topography, horizontal divergence of plate motions, and the Fennoscandian relaxation spectrum) associated with mantle convection and glacial isostatic adjustment (GIA), and this well-derived viscosity profile was used in the present study for estimating the value of $\eta_{\mathrm{av}}$.

The effective radius of the slab can be estimated either through approximation of edgewise translation of an ellipsoid through a viscous medium (Lamb 1993; Scholz and Campos 1995) or equivalence to the volume of a rigid sphere. Moreover, the inconsistent configurations of the subducting slabs allowed us for deriving the effective radii of the slabs in the three sectors (Table 1) through the following equation

$r_{\mathrm{e}}=\left(\frac{3 V}{4 \pi}\right)^{\frac{1}{3}}$

\section{Results}

The computed values of plate-driving forces along the Andaman-Sumatra margin are illustrated in Table 1. The value of $F_{\text {SP }}$ (down-dip component of the slab pull force) is the smallest (i.e. $1.29 \times 10^{13} \mathrm{~N} / \mathrm{m}$ ) in sectors I (near Andaman) and the largest (i.e. $2.10 \times 10^{13} \mathrm{~N} / \mathrm{m}$ ) in sector II (near Great Nicobar), respectively. Value of $F_{\text {SP }}$ in Sector III (near Sumatra) is nearly equal to that of sector II. In contrast, the value of $F_{\mathrm{SR}}$ is the largest (i.e. $2.72 \times$ $10^{13} \mathrm{~N} / \mathrm{m}$ ) in sector III, and the minimum value (i.e. $\left.1.13 \times 10^{13} \mathrm{~N} / \mathrm{m}\right)$ is noted in sector II. While the intermediate $F_{\text {SR }}$ value (i.e. $1.41 \times 10^{13} \mathrm{~N} / \mathrm{m}$ ) is noted in sector II. The wide variation of both these forces is apparently complied with the inhomogeneous trench-parallel rupture, seismic energy bursts (Ishii et al. 2005; Lay et al. 2005; Ammon et al. 2005; Mishra et al. 2010), dip of the descending oceanic lithosphere (Khan and Chakraborty 2005), and trench-normal subduction rate (Fig. 1). It can further be demonstrated that the relative extent between 
$F_{\mathrm{SR}}$ and $F_{\mathrm{SP}}$ (Fig. 3 ) is also varied reasonably in the three sectors, and $F_{\mathrm{SR}}-F_{\mathrm{SP}}$ is positive in sectors I and III, and vice versa in sector II. The least value of $F_{\mathrm{SR}}-F_{\mathrm{SP}}$ $\left(0.12 \times 10^{13} \mathrm{~N} / \mathrm{m}\right)$, and higher dip of the descending lithosphere (Khan and Chakraborty 2005) in sector I apparently comply with the occurrence of relatively smaller magnitude earthquakes towards north (discussed before) around Andaman area and also support the absence of intermediate-depth aftershocks following the 2004 Sumatra mega-event (Mishra et al. 2010). Here, the descending lithosphere in this area is possibly decoupled from the overriding plate (e.g. northeast Japan forearc, Mishra et al. 2003). The comparatively lower seismic energy burst during 2004 earthquake (Ishii et al. 2005) in Andaman area also corroborates this observation. Instead, the negative value of $F_{\mathrm{SR}}-F_{\mathrm{SP}}$ (Figs. 1, 3) accounts for the minimum seismic energy burst near Great Nicobar area (sector II), and the slab is presumably being supported from surface plate at the trench. Alternatively, the highest positive value of $F_{\mathrm{SR}}-F_{\mathrm{SP}}$ in sector III led the descending slab being supported from below in the surrounding mantle (Forsyth and Uyeda 1975; Conrad and Lithgow-Bertelloni 2002), and the shallower part (e.g. flexing zone) of the lithosphere experiences compressive stress field. This is presumably due to superposition of pulsating stresses on the long-term time average or steady bending stresses (Rice and Stuart 1989; Taylor et al. 1996; Khan and Chakraborty 2009) along the longitudinal profile of the descending oceanic slab in Sumatra area (sector III). The pulsating periodic stress was clearly initiated from the uncompensated slab resistive force (Christensen and Ruff 1988; Astiz et al.

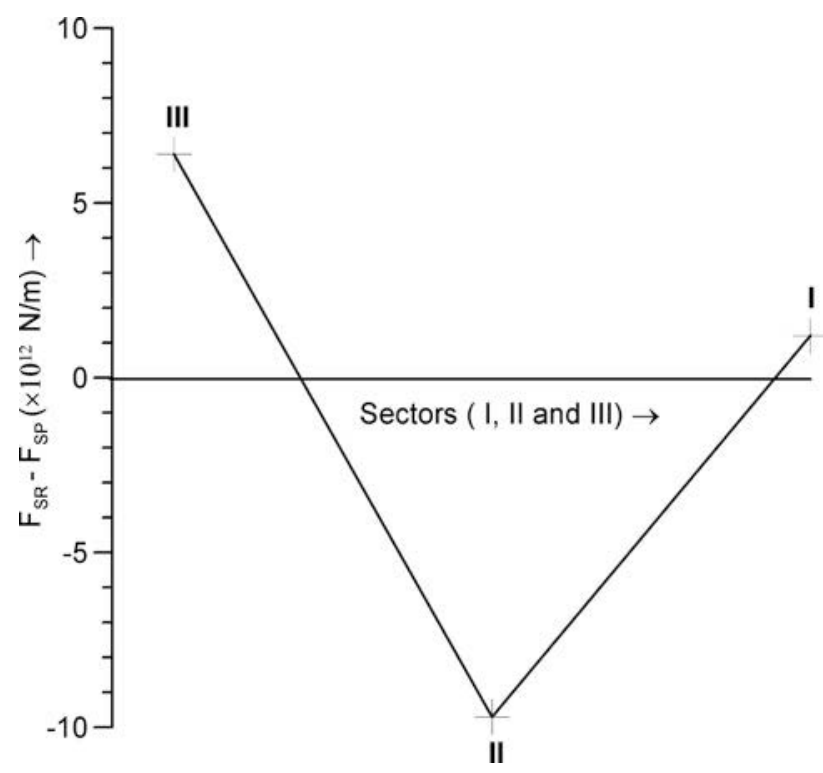

Fig. 3 Plot showing the sector-specific relative extent between slab resistive and slab pull forces (i.e. $F_{\mathrm{SR}}-F_{\mathrm{SP}}$ )
1988; Lay et al. 1989). It is also appreciated in the literature (Forsyth and Uyeda 1975) that the mutual interaction between $F_{\mathrm{SR}}$ and $F_{\mathrm{SP}}$ along the longitudinal profile of the descending lithosphere is responsible for generating either extensional or compressional earthquakes at shallow depths for $F_{\mathrm{SR}}<F_{\mathrm{SP}}$ or $F_{\mathrm{SR}}>F_{\mathrm{SP}}$, respectively. It was also observed elsewhere that the local intraslab seismicity is occasionally being evolved by the interaction between local tectonics and bending stresses (Mishra and Zhao 2004). This may allow for more interdisciplinary research to better understanding the tectonics, rheology, and stress state of the subducting slabs.

The reconstructed Benioff zones shown in Fig. 4 illustrate the operation of slab resistive force and down-dip and normal component of slab pull force on the hanging
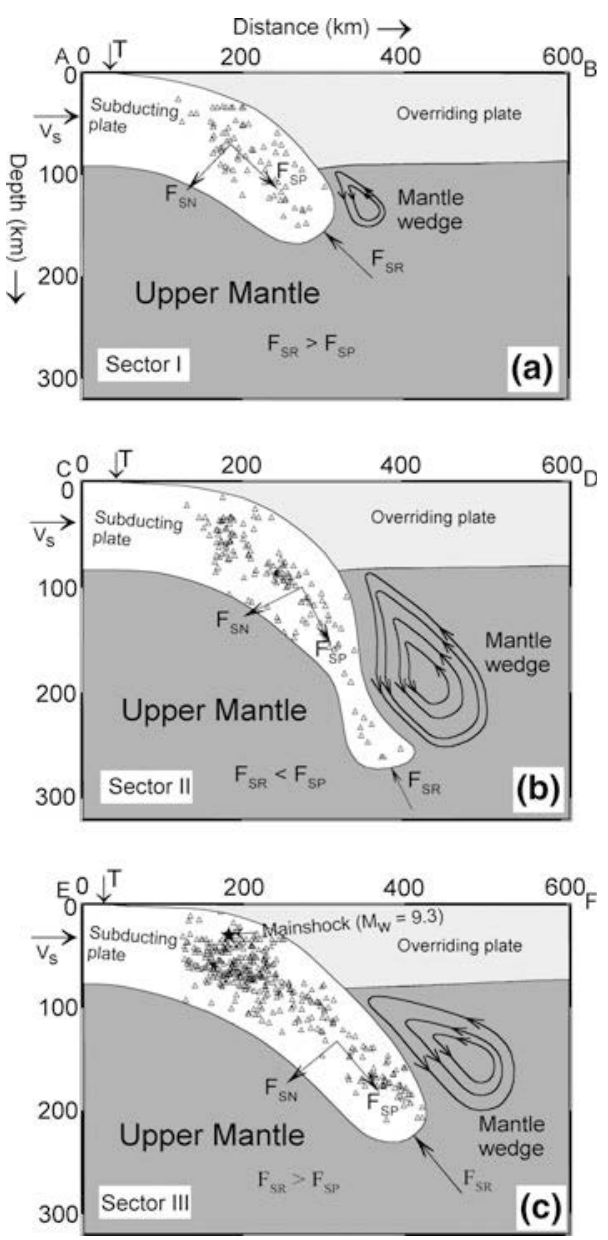

Fig. 4 Model indicates the penetration of the oceanic Indian lithosphere, reconstructed through distribution of hypocenters, and subducting plate age, into the mantle in the three sectors I, II, and III. $F_{\mathrm{SP}}, F_{\mathrm{SN}}$, and $F_{\mathrm{SR}}$ acting within the descending lithosphere are represented by arrows. $V_{\mathrm{S}}$ represents the trench-normal subduction rate. Convection cell trajectories were reconstructed after the works of Kincaid and Sacks (1997) and Hyndman and Peacock (2003). Note the sector-specific trade-off between $F_{\mathrm{SP}}$ and $F_{\mathrm{SR}} . T$ in the model represents the sector-specific location of the trench 
lithosphere in three sectors along the Andaman-Sumatra margin. Oceanic lithosphere generally descends into the mantle with near-terminal velocities at most subduction margins around the world (Forsyth and Uyeda 1975). However, a comparison between trench-normal subduction rate and angle of subduction based on corner flow model (Stevenson and Turner 1977; Tovis et al. 1978) commonly indicates a steady equilibrium of a subducting lithosphere at a particular angle greater than the critical angle $\left(\theta_{\mathrm{c}}=\sim 63^{\circ}\right)$ after attaining a specific negative buoyancy force. However, for dip with less than critical value (i.e. $\theta_{\mathrm{c}}<63^{\circ}$ ) the descending lithosphere can never achieve its stability (Stevenson and Turner 1977), and moreover, experiment (Guillou-Frottier et al. 1995; King 2001) indicates that subduction is not a steady phenomenon, and significant deformation of the slab at different depth level is inevitable. It is thus may be summarized that the slab may undergoes unstable equilibrium with significant deformation for dipping angle less than its critical value, and this critical condition can sometimes be achieved by hydrodynamic lifting towards the overriding plate. However, the hydrodynamic lifting force is generally balanced by counter action of $F_{\mathrm{SN}}$ (Forsyth and Uyeda 1975). In any case, the shallower dips $\left(\theta \mathrm{c}<63^{\circ}\right)$ of the slabs (Fig. 3 of Khan and Chakraborty 2005) in sectors II and III clearly account for instability of the descending lithosphere, and the relative extent of $F_{\mathrm{SR}}$ over $F_{\mathrm{SP}}$ (i.e. $F_{\mathrm{SR}}-F_{\mathrm{SP}}=$ $0.64 \times 10^{13} \mathrm{~N} / \mathrm{m}$, refer Table 1$)$ in sector III might be responsible for the occurrence of 2004 off Sumatra megaevent. Higher dip of the slab towards its northernmost sector possibly allowed volcanicity around the Barren and Narcondum areas and that somehow caused crustal weakening during enhanced convective circulation process in the mantle wedge (cf. Zhao et al. 2002) leading to an energy burst during 2004 event around North Andaman area (Ishii et al. 2005; Mishra et al. 2010).

\section{Discussion}

The geodynamic processes at the converging plate boundaries are generally complicated. The trench-normal component of the convergence allows the slab to sink into the mantle, and the trench-parallel component leads the tangential motion of the slab. Therefore, the plate obliquity plays an important role in reconstruction of the tectonic setting along oblique subduction margin. Further, the penetration of the converging plate into the mantle is primarily controlled by the balance of forces acting on the descending slabs, and the major plate-driving slab pull force is normally emphasized to account for the shallowlevel intraplate down-dip extensional failures (Christova and Scholz 2003; Seno and Yoshida 2004). The megathrust failure instead are interpreted in terms of either interplate coupling or seamounts/asperity subduction, and the effect of slab resistive force behind the occurrence of large earthquakes along subduction margins was hardly addressed. Moreover, the interplate coupling and/or seamount subduction hypotheses remained conjectural as studies by different workers resulted contradictory viewpoints (Christensen and Ruff 1988; Pacheco et al. 1993). Besides, fore bearers of asperity subduction hypothesis (Ruff and Kanamori 1983; Cloos and Shreve 1996) noticed coincidence of distinct bend in Benioff zone configuration with the most active zone of seismic slip accumulation in many of the subduction margins around $30-40 \mathrm{~km}$ depth. The high-resolution reconstruction of depth-dip angle profiles across the Sumatra margin (Khan and Chakraborty 2005) showed minimum dip and attainment of early (around $25 \mathrm{~km}$ depth) dip angle saturation in Benioff zone trajectory in sector III, and the slip/stress vector residual was noted to be minimum (nearly zero, Liu et al. 1995; Khan 2007). It is therefore may be proposed that the occasional incidences of great earthquakes around Sumatra plate margin were somehow associated with the spatio-temporal changes of the plate obliquity, subduction rate, and depth of plate flexing (Khan and Chakraborty 2005). Trenchparallel thrust dominated movements in sector III and trench-parallel shear dominated movements in sector II under static stress field (Khan 2007) also comply with the dynamic imbalance between $F_{\mathrm{SP}}$ and $F_{\mathrm{SR}}$, and the net force (i.e. $F_{\mathrm{SR}}-F_{\mathrm{SP}}$ ) estimated in sector III rightly indicates higher compressive stress accumulation within the shallower part (i.e. flexing zone) of the descending lithosphere.

Occasional incidences of great earthquakes over a span of last 200 years and recurrence of seismic energy burst during the 2004 off Sumatra mega-event can further be visualized in the backdrop of major late Tertiary geological events along this Andaman-Sumatra margin. Large-scale subsidence of the forearc and opening of Mergui-Sumatra basin near the northwest Sumatra were interpreted in terms of late Oligocene deformation of the descending lithosphere. Further, the region in the vicinity of southeast Sumatra documents plate obliquity just greater than its critical value and that triggered the trench-parallel shear motion. The late Miocene-Pliocene pull-apart opening of the Andaman Sea from the same area was also associated with the anomalous deformation of the lithosphere (Khan and Chakraborty 2005). Moreover, the region records minimum dip (less than critical value) of the descending lithosphere over this entire Sunda margin. These features usually allow the slab to accumulate more stress around the flexing zone resulting from dynamic imbalance between $F_{\text {SR }}$ and $F_{\text {SP }}$ over decades, and occasionally released through intraplate shallow-level thrust failure in the descending slab around the Sumatra region. It is thus 
proposed that the plate-driving forces had a definite control on the occurrence of 2004 off Sumatra event and apparently associated with shallow-level flexing zone of the lithosphere. A causal relationship between these major plate-driving forces and the geodynamic processes established under the present study for the Andaman-Sumatra margin clearly indicates that 2004 off Sumatra megaearthquake was not unexpected in this area.

\section{Conclusions}

We have estimated the major plate-driving forces i.e. slab pull and slab resistive in three specific sectors along the Andaman-Nicober-Sumatra subduction margin and found a strong correlation between the seismic energy burst and unbalanced components of these forces. We propose that the bending stress around the flexing zone was enhanced by the superimposition of excess slab resistive force in Sumatra sector. The combined stress around the flexing zone subsequently exceeds the yield point stress of the material and provoked thrust movement along a shallowly dipping $\left(\sim 8^{\circ}\right)$ plane releasing maximum energy on 26th December 2004. The release of seismic energy suddenly drops to a minimum towards north near Great Nicober where the descending plate was documenting tension at the shallower part. Farther towards north, the flexing zone of the trench-hanging lithosphere recorded a little excess of slab resistive force where the third seismic energy burst was identified. The mutual interaction between enhanced convective circulation in the mantle wedge and the stress field in the flexing zone might have a positive role behind the generation of lower seismic energy burst near North Andaman.

Acknowledgments The author is thankful to the Director, Indian School of Mines, Dhanbad for providing the infrastructure facilities. This work has benefited from critical interaction with eminent earth scientists during its presentation on July 29, 2009 in the monthly lecture programme of the Geological Society of India, Bangalore. I thank O. P. Mishra and an anonymous reviewer for constructive comments, which improved the manuscript.

Open Access This article is distributed under the terms of the Creative Commons Attribution Noncommercial License which permits any noncommercial use, distribution, and reproduction in any medium, provided the original author(s) and source are credited.

\section{References}

Ammon CJ, Ji C, Thio HK et al (2005) Rupture process of the 2004 Sumatra-Andaman earthquake. Science 308:1133-1139

Astiz L, Lay T, Kanamori H (1988) Large intermediate depth earthquakes and the subduction process. Phys Earth Planet Int 53:80-166
Barber AJ, Crow MJ (2003) An evaluation of plate tectonic models for the development of Sumatra. Gond Res 6:1-28

Christensen DH, Ruff LJ (1988) Seismic coupling and outer rise earthquakes. J Geophys Res 93:13421-13444

Christova C (2004) Stress field in the Ryukyu-Kyushu WadatiBenioff zone by inversion of earthquake focal mechanisms. Tectonophysics 384:175-189

Christova C, Scholz CH (2003) Stresses in the Vanuatu subducting slab: a test of two hypothesis. Geophys Res Letts 30:1790-1793

Cloos M (1993) Lithospheric buoyancy and collision orogenesis: subduction of oceanic plateaus, continental margins, island arcs, spreading ridges, and seamounts. Geol Soc Am Bull 105: $715-737$

Cloos M, Shreve R (1996) Shear-zone thickness and the seismicity of Chilean and Marianas-type subduction zones. Geol 24:107-110

Conrad CP, Hager BH (1999) Effects of plate bending and fault strength at subduction zones on plate dynamics. J Geophys Res 104:17551-17571

Conrad CP, Lithgow-Bertelloni C (2002) How mantle slabs drive plate tectonics. Science 298:207-209

Corrieu V, Ricard Y, Froidevaux C (1994) Converting mantle tomography into mass anomalies to predict the Earth's radial viscosity. Phys Earth Planet Int 84:3-13

Curray JR (2005) Tectonics and history of the Andaman Sea region. J Asian Earth Sci 25:187-232

Curray JR, Munasinghe T (1991) Origin of the Rajmahal Traps and the 85 E Ridge: Preliminary reconstructions of the trace of the Crozet hotspot. Geol 19:1237-1240

Dasgupta S, Mukhopadhyay M, Bhattacharya A et al (2003) The geometry of the Burma-Andaman subducting lithosphere. J Seism 7:155-174

Dasgupta S, Mukhopadhyay B, Acharyya A (2005) Aftershock propagation characteristics during the first three hours following the 26 December 2004 Sumatra-Andaman earthquake. Gond Res 8:585-588

Diament M, Harjono H, Karta K et al (1992) Mentawai fault zone off Sumatra: A new key to the geodynamics of western Indonesia. Geol 20:259-262

Dmowska R, Zheng G, Rice JR (1996) Seismicity and deformation at convergent margins due to heterogeneous coupling. J Geophys Res 101:3015-3029

Elsasser WM (1969) Convection and stress propagation in the upper mantle. In: Runcorn SK (ed) The Application of Modern Physics to the Earth and Planetary Interiors. Wiley Interscience, London, pp 223-246

Fitch TJ (1972) Plate convergence, transcurrent faults and internal deformation adjacent to southeast Asia and western Pacific. J Geophys Res 77:4432-4460

Forsyth DW, Uyeda S (1975) On the relative importance of the driving forces of plate motion. Roy Astron Soc Geophys J 43:163-200

Guillou-Frottier L, Buttles J, Olson P (1995) Laboratory experiments on the structure of subducted lithosphere. Earth Planet Sci Letts 133:19-34

Hager BH, O'Connell RJ (1978) Subduction zone dip angles and flow driven by plate motion. Tectonophysics 50:111-133

Hall R (1997) Cenozoic plate tectonic reconstructions of SE Asia. In: Fraser AJ, Matthews SJ, Murphy RW (eds) Petroleum geology of Southeast Asia, Geological Society of London, Spec Pub 126, pp 11-23

Harper JF (1975) On the driving forces of plate tectonics. Roy Astron Soc Geophys J 40:465-474

Hyndman RD, Peacock SM (2003) Serpentinization of the forearc mantle. Earth Planet Sci Letts 212:417-432

Isacks B, Molnar P (1969) Mantle earthquakes mechanisms and the sinking of the Lithosphere. Nature 223:1121-1124 
Isacks B, Molnar P (1971) Distribution of stresses in the descending lithosphere from a global survey of focal-mechanism solutions of mantle earthquakes. Rev Geophys Space Phys 9:103-175

Ishii M, Shearer PM, Houston H et al (2005) Extent, duration and speed of the 2004 Sumatra-Andaman earthquake imaged by the hi-net array. Nature 435:933-936

Khan PK (2007) Lithospheric deformation under pre- and postseismic stress fields along the Nicobar-Sumatra subduction margin during 2004 Sumatra mega-event and its tectonic implications. Gond Res 12:468-475

Khan PK, Chakraborty PP (2005) Two-phase opening of Andaman Sea: A new seismotectonic insight. Earth Planet Sci Letts 229:259-271

Khan PK, Chakraborty PP (2009) Bearing of plate geometry and rheology on shallow-focus mega-thrust seismicity with special reference to 26 December 2004 Sumatra event. J Asian Earth Sci 34:480-491

Kincaid C, Sacks IS (1997) Thermal and dynamical evolution of the upper mantle in subduction zones. J Geophys Res 102: $12295-12315$

King SD (2001) Subduction zones: observations and geodynamic models. Phys Earth Planet Int 127:9-24

King SD, Masters TG (1992) An inversion for the radial viscosity structure using seismic tomography. Geophys Res Letts 19:1551-1554

Lamb C (1993) Hydrodynamics, 6th edn. Cambridge University Press, New York, p 738

Lay T, Astiz L, Kanamori H et al (1989) Temporal variation of large intraplate earthquakes in coupled subduction zones. Phys Earth Planet Int 54:258-312

Lay T, Kanamori H, Ammon CJ et al (2005) The great SumatraAndaman earthquake of 26 December 2004. Science 308: $1127-1133$

Le Dain AY, Tapponnier P, Molnar P (1984) Active faulting and tectonics of Burma and surrounding regions. J Geophys Res $89: 453-472$

Lithgow-Bertelloni C, Richards MA (1998) The dynamics of Cenozoic and Mesozoic plate motions. Rev Geophys 36:27-78

Liu X, McNally KC, Shen Z-K (1995) Evidence for a role in the downgoing slab in earthquake slip partitioning at oblique subduction zones. J Geophys Res 100:15351-15372

Marotta AM, Mongelli F (1998) Flexure of subducted slabs. Geophys J Int 132:701-711

Maung H (1987) Transcurrent movements in the Burma-Andaman sea region. Geol 15:911-912

McCaffrey R, Zwick PC, Bock Y et al (2000) Strain partitioning during oblique plate convergence in northern Sumatra: Geodetic and seismologic constraints and numerical modeling. J Geophys Res 105:28363-28376

McKenzie D (1969) Speculations on the consequences and causes of plate motions. Roy Astron Soc Geophys J 18:1-32

Metcalfe I (2006) Palaeozoic and Mesozoic tectonic evolution and palaeogeography of East Asian crustal fragments: the Korean Peninsula in context. Gond Res 9:24-46

Mishra OP, Zhao D (2004) Seismic evidence for dehydration embrittlement of the subducting Pacific slab. Geophys Res Lett 31:L09610. doi:10.1029/2004GL019489

Mishra OP, Zhao D, Umiino N et al (2003) Tomography of northeast Japan forearc and its implications for interplate seismic coupling. Geophys Res Lett 30:1850. doi:10.1029/2003GL017736

Mishra OP, Kayal JR, Chakrabortty GK et al (2007) Aftershock investigation in the Andaman-Nicobar islands of India and its seismotectonic implications. Bull Seism Soc Am 97:S71-S85. doi:10.1785/0120050629

Mishra OP, Zhao D, Chakraborty GK et al. (2010) Role of crustal heterogeneity beneath Andaman-Nicobar Islands and its implications for coastal hazard. Natural Hazards, Special issue, no. NHAZ1042 (in press)

Mitrovica JX (1996) Haskell [1935] revisited. J Geophys Res 101:555-569

Mitrovica JX, Forte AM (2004) A new inference of mantle viscosity based upon joint inversion of convection and glacial isostatic adjustment data. Earth Planet Sci Letts 225:177-189

Muller RD, Roest WR, Royer JY et al (1997) Digital isochrones of the world's ocean floor. J Geophys Res 102:3211-3214

Nakada M, Lambeck K (1989) Late Pleistocene and Holocene sea level change in the Australian region and mantle viscosity. Geophys J Int 96:497-517

Ninkovich D (1976) Late Cenozoic clockwise rotation of Sumatra. Earth Planet Sci Letts 29:269-275

Pacheco JF, Sykes LR, Scholz CH (1993) Nature of seismic coupling along simple plate boundaries of the subduction type. J Geophys Res 98:14133-14159

Panasyuk SV, Hager BH (2000) Inversion for mantle viscosity profiles constrained by dynamic topography and the geoid, and their estimated errors. Geophys J Int 143:821-836

Parsons B, Richter FM (1980) A relation between the driving force and geoid anomaly associated with the mid-ocean ridges. Earth Planet Sci Letts 51:445-450

Patriat P, Achache J (1984) India-Eurasia collision chronology has implications for crustal shortening and driving mechanism of plates. Nature 311:615-621

Paul J, Bürgmann R, Gaur VK et al (2001) The motion and active deformation of India. Geophys Res Letts 28:647-650

Peterson ET, Seno T (1984) Factors affecting seismic moment release rates in subduction zones. J Geophys Res 89:1023310248

Ponko SC, Peacock SM (1995) Thermal modeling of the southern Alaska subduction zone: insight into the petrology of the subducting slab and overlying mantle wedge. J Geophys Res 100:22117-22128

Prawirodirdjo L, Bock Y, McCaffrey R et al (1997) Geodetic observations of interseismic strain segmentation at the Sumatra subduction zone. Geophys Res Letts 24:2601-2604

Raju KAK, Ramprasad T, Rao PS et al (2004) New insights into the tectonic evolution of the Andaman basin, northeast Indian Ocean. Earth Planet Sci Letts 7024:1-18

Rice JR, Stuart WD (1989) Stressing in and near a strongly coupled subduction zone during the earthquake cycle. EOS Trans AGU 70:1063 (abstract)

Richardson RM (1992) Ridge forces, absolute plate motions, and the intraplate stress field. J Geophys Res 97:11739-11748

Richardson RM, Solomon SC, Sleep NH (1979) Tectonic stress in the plates. Rev Geophys 17:981-1019

Ruff L, Kanamori H (1983) The rupture process and asperity distribution of three great earthquakes from long-period diffracted P-waves. Phys Earth Planet Int 31:202-230

Scholz CH, Campos J (1995) On the mechanism of seismic decoupling and back arc spreading at subduction zones. J Geophys Res 100:22103-22115

Seno T, Yoshida M (2004) Where and why do large shallow intraslab earthquakes occur? Phys Earth Planet Int 141:183-206

Solomon SC, Sleep NH, Richardson RM (1975) On the forces driving plate tectonics: inferences from absolute plate velocities and intraplate stress. Roy Astron Soc Geophys J 42:769-801

Stein S, Okal EA (2005) Speed and size of the Sumatra earthquake. Nature 134:581-582

Stevenson DJ, Turner JS (1977) Angle of subduction. Nature 270:334-336

Taylor MAJ, Zheng G, Rice JR (1996) Seismicity and deformation at convergent margins due to heterogeneous coupling. J Geophys Res 101:8363-8381 
Tovis A, Schubert G, Luyendyk BP (1978) Mantle flow pressure and the angle of subduction; non-Newtonian corner flows. J Geophys Res 83:5892-5898

Turcotte DL, Schubert G (1982) Geodynamics: Applications of Continuum Physics to Geological Problems. Willey, New York, p 450

Walter TR, Amelung F (2007) Volcanic eruptions following M $>9$ megathrust earthquakes: implications for the Sumatra-Andaman volcanoes. Geol Soc Am 35:539-542
Watts AB, Burov EB (2003) Lithospheric strength and its relationship to the elastic and seismogenic layer thickness. Earth Planet Sci Letts 213:113-131

Widiyantoro S, van der Hilst R (1997) Mantle structure beneath Indonesia inferred from high-resolution tomographic imaging. Geophys J Int 130:167-182

Zhao D, Mishra OP, Sanda R (2002) Influence of fluids and magma on earthquakes: seismological evidence. Phys Earth Planet Int 132:249-267 